\title{
Auditory Fear Conditioning and Long-Term Potentiation in the Lateral Amygdala Require ERK/MAP Kinase Signaling in the Auditory Thalamus: A Role for Presynaptic Plasticity in the Fear System
}

\author{
Annemieke M. Apergis-Schoute, ${ }^{1}$ Jacek Dębiec, ${ }^{1}$ Valérie Doyère, ${ }^{1,2}$ Joseph E. LeDoux, ${ }^{1}$ and Glenn E. Schafe ${ }^{3}$ \\ ${ }^{1}$ W. M. Keck Foundation Laboratory of Neurobiology, Center for Neural Science, New York University, New York, New York $10003,{ }^{2}$ Neurobiologie de \\ l'Apprentissage, de la Mémoire, et de la Communication, Unité Mixte de Recherche 8620, Centre National de la Recherche Scientifique-Université Paris \\ Sud, 91405 Orsay, France, and ${ }^{3}$ Department of Psychology and Interdisciplinary Neuroscience Program, Yale University, New Haven, Connecticut 06520
}

In the present study, we examined the role of the auditory thalamus [medial division of the medial geniculate nucleus and the adjacent posterior intralaminar nucleus ( $\mathrm{MGm} / \mathrm{PIN})$ ] in auditory pavlovian fear conditioning using pharmacological manipulation of intracellular signaling pathways. In the first experiment, rats were given intrathalamic infusions of the MEK (mitogen-activated protein kinase kinase) inhibitor 1,4-diamino-2,3-dicyano-1,4-bis(o-aminophenylmercapto) butadiene (U0126) before fear conditioning. Findings revealed that long-term memory (assessed at $24 \mathrm{~h}$ ) was impaired, whereas short-term memory (assessed at 1-3 h) of fear conditioning was intact. In the second experiment, rats received immediate posttraining intrathalamic infusion of U0126, the mRNA synthesis inhibitor 5,6-dichloro-1- $\beta$-D-ribofuranosylbenzimidazole (DRB), or infusion of the protein synthesis inhibitor anisomycin. Posttraining infusion of either U0126 or DRB significantly impaired long-term retention of fear conditioning, whereas infusion of anisomycin had no effect. In the final experiment, rats received intrathalamic infusion of U0126 before long-term potentiation (LTP)-inducing stimulation of thalamic inputs to the lateral nucleus of the amygdala (LA). Findings revealed that thalamic infusion of U0126 impaired LTP in the LA. Together, these results suggest the possibility that MGm/PIN cells that project to the LA contribute to memory formation via ERK (extracellular signal-regulated kinase)-mediated transcription, but that they do so by promoting protein synthesis-dependent plasticity locally in the LA.

Key words: amygdala; medial geniculate; fear conditioning; LTP; MAP kinase; rat

\section{Introduction}

Classical fear conditioning is a form of associative learning in which an emotionally neutral conditioned stimulus (CS), such as a tone, is paired with an aversive unconditioned stimulus (US), such as an electric footshock. After CS-US pairing, the CS acquires aversive properties and comes to elicit defensive behaviors, including freezing and changes in autonomic nervous system reactivity (Blanchard and Blanchard, 1969; Kapp et al., 1979; Davis et al., 1997; LeDoux, 2000).

The mechanisms of fear conditioning are best understood for auditory fear conditioning (LeDoux, 2000; Maren, 2001). Auditory information reaches the auditory thalamus, specifically the

Received Jan. 9, 2005; revised May 2, 2005; accepted May 8, 2005.

This research was supported in part by National Institute of Mental Health Grants MH 46516, MH 00956, MH 39774, MH 11902 and MH 570161 (J.E.L.), and MH 62519 (G.E.S.) and by Centre National de la Recherche Scientifique-National Science Foundation Grant 17089 (V.D.). The work was also supported by a grant from the W. M. Keck Foundation to New York University. We thank Torfi Sigurdsson and Yu Zhou for assistance with the electrophysiological experiments and Dr. Jean-Marc Edeline for helpful discussions.

Correspondence should be addressed to Dr. Glenn E. Schafe, Department of Psychology, Yale University, 2 Hillhouse Avenue, Box 208205, New Haven, CT 06520. E-mail: glenn.schafe@yale.edu.

D01:10.1523/JNEUROSCI.0096-05.2005

Copyright $\odot 2005$ Society for Neuroscience $\quad$ 0270-6474/05/255730-10\$15.00/0 medial division of the medial geniculate nucleus and the adjacent posterior intralaminar nucleus (MGm/PIN) and from there is transmitted to the amygdala and auditory cortex (LeDoux et al., 1990; Doron and Ledoux, 1999). The lateral nucleus of the amygdala (LA) is the largest recipient of sensory inputs from the thalamus and cortex (Romanski and LeDoux, 1993; McDonald, 1998) and serves both as the sensory interface of the amygdala and a critical site of plasticity during fear conditioning (LeDoux, 2000; Blair et al., 2001; Maren, 2001). Lesion, inactivation, electrophysiological, and pharmacological studies have all provided strong evidence that the LA is a key site in which critical elements of the CS-US association are encoded and stored during auditory fear conditioning (Quirk et al., 1995; McKernan and ShinnickGallagher, 1997; Rogan et al., 1997; Fendt and Fanselow, 1999; Maren, 1999; LeDoux, 2000; Schafe et al., 2001).

In contrast to the LA, much less is known about the role of the auditory thalamus in fear conditioning. Cells within the MGm/ PIN, like those in LA, rapidly develop increased firing to the CS after auditory fear conditioning (Gabriel et al., 1975; Birt and Olds, 1981; Weinberger, 1982; Hennevin et al., 1998) and also exhibit long-term potentiation (LTP) (Gerren and Weinberger, 1983). Furthermore, receptive field analysis of the MGm during 
auditory fear conditioning shows the development and maintenance of highly specific plasticity, including shifts of tuning to the frequency of the CS (Edeline and Weinberger, 1992; Lennartz and Weinberger, 1992). Despite the numerous studies that have documented electrophysiological changes in the thalamus after fear conditioning, few, however, have to date asked what the behavioral significance of such plasticity might be.

In this study, we examined the impact of localized intrathalamic infusions of a mitogen-activated protein (MAP) kinase kinase (MEK) inhibitor, an mRNA synthesis inhibitor, and a protein synthesis inhibitor on the acquisition and retention of auditory fear conditioning. These pharmacological treatments are known to block synaptic plasticity and fear memory formation in the LA (Bailey et al., 1999; Huang et al., 2000; Schafe and LeDoux, 2000; Schafe et al., 2000). We demonstrate that inhibition of extracellular signal-regulated kinase/ MAP kinase (ERK/MAPK) activation or of mRNA synthesis in the auditory thalamus impairs fear memory consolidation, whereas disruption of protein synthesis has no effect. We also show that inhibition of ERK/MAPK activation in the auditory thalamus impairs LTP in the LA. Collectively, our findings support the intriguing possibility that the auditory thalamus contributes to fear memory formation via ERK-mediated transcription but is not itself a site of protein synthesisdependent memory storage. Rather, ERK signaling in the $\mathrm{MGm} / \mathrm{PIN}$ may act to promote plasticity and fear memory formation locally in the LA.

\section{Materials and Methods}

Subjects. Adult male Sprague Dawley rats (Hilltop, Scottdale, PA) were housed individually in plastic Nalgene cages on a $12 \mathrm{~h}$ light/dark cycle. Food and water were provided ad libitum throughout the experiment. All procedures were approved by the New York University Animal Care and Use Committee.

Surgery. Rats were anesthetized with Nembutal (45 mg/kg, i.p.; Henry Schein, Melville, NY) and implanted bilaterally with 26 gauge stainlesssteel guide cannulas aimed at the auditory thalamus (MGm/PIN). Coordinates were $-5.4 \mathrm{~mm}$ anteroposterior (AP), $+3.0 \mathrm{~mm}$ mediolateral (ML), and $-6.6 \mathrm{~mm}$ dorsoventral (DV). The guide cannulas were fixed to screws in the skull with dental cement, and a dummy cannula was inserted into each guide to prevent clogging. After surgery, rats were administered buprenorprhine $\mathrm{HCl}(0.02 \mathrm{mg} / \mathrm{kg})$ for analgesia. Rats were given at least $5 \mathrm{~d}$ to recover before experimental procedures.

Drugs. 1,4-diamino-2,3-dicyano-1,4-bis (o-aminophenylmercapto) butadiene (U1026) (catalog \#V1121; Promega, Madison, WI) and 5,6dichloro-1- $\beta$-D-ribofuranosylbenzimidazole (DRB) (catalog \#D1916; Sigma, St. Louis, MO) were dissolved in 100\% DMSO and then diluted 50:50 with artificial CSF (ACSF) to yield final concentrations of $2 \mu \mathrm{g} / \mu \mathrm{l}$ and $36 \mathrm{ng} / \mu \mathrm{l}$, respectively. Anisomycin (catalog \#A9789; Sigma) was first dissolved in equimolar $\mathrm{HCl}$ and then diluted 50:50 with ACSF to yield final concentrations of either $250 \mu \mathrm{g} / \mu \mathrm{l}$ (high dose) or $125 \mu \mathrm{g} / \mu \mathrm{l}$ (low dose). In all experiments, rats received intrathalamic infusion of drug or vehicle solutions in $0.5 \mu \mathrm{l}$ volumes and at a rate of $0.2 \mu \mathrm{l} / \mathrm{min}$.

General behavioral procedures. On the day before conditioning, rats were habituated to the conditioning chamber for $15 \mathrm{~min}$ and to dummy cannula removal and replacement. On the following day, they were conditioned using either five pairings (strong training) or one pairing (weak training) of a $20 \mathrm{~s}, 5 \mathrm{kHz}, 75 \mathrm{~dB}$ tone that coterminated with a $0.5 \mathrm{~s}, 1.0$ $\mathrm{mA}$ footshock (US). In some experiments, rats received intrathalamic infusion of vehicle ( $50 \%$ DMSO; $0.5 \mu \mathrm{l}$ ) or one of two doses of U0126 in $50 \%$ DMSO ( 1.0 or $0.1 \mu \mathrm{g} /$ side) 30 min before training (see Figs. 1, 2). In other experiments, rats received an immediate posttraining infusion of $50 \%$ DMSO vehicle, U0126 ( 1 or $2 \mu \mathrm{g} / \mathrm{side}$ ), one of two doses of anisomycin ( 62.5 or $125 \mu \mathrm{g} / \mathrm{side}$ ), or infusion of DRB (16 ng/side) (see Fig. 3).
After each infusion, injectors remained in the cannulas for $1 \mathrm{~min}$ to allow diffusion of the fluid from the tip.

In all experiments, rats were tested for retention of auditory fear conditioning at the specified time points (see Results). Retention testing consisted of presentation of $20 \mathrm{~s}, 5 \mathrm{kHz}, 75 \mathrm{~dB}$ tones and always occurred in a brightly lit distinct chamber with a flat black plastic floor that had been washed with a distinctive peppermint soap (for details, see Schafe et al., 2000). Total seconds of freezing during each CS presentation were scored for each rat, and this number was expressed as a percentage of the total CS presentation time. For simplicity, all trials within each memory test were averaged into a single score for each animal. All data were analyzed with Student's $t$ tests or ANOVA and post hoc $t$ tests when appropriate. Differences were considered significant if $p<0.05$.

At the end of each behavioral experiment, rats were anesthetized by an overdose of chloral hydrate $(600 \mathrm{mg} / \mathrm{kg})$ and perfused with $10 \%$ buffered Formalin. Nissl staining and light microscopy were used to verify the location of the cannula tips within the MGm/PIN.

Electrophysiology. Adult rats (300-350 g) were anesthetized with urethane (two intraperitoneal injections at $10 \mathrm{~min}$ intervals; total of 1.6 $\mathrm{mg} / \mathrm{kg}$ ) and placed in a stereotaxic frame. The skull was exposed over the $\mathrm{MGm} / \mathrm{PIN}$ and LA, and the dura was retracted. Rats were implanted with an insulated bipolar stimulating electrode into the MGm/PIN that was adhered to a stainless-steel 26 gauge cannula (Plastics One, Roanoke, VA). A glass recording pipette (0.5-8 $\mathrm{M} \Omega$ ) filled with $150 \mathrm{~mm}$ sodium acetate $2.5 \%$ pontamine sky blue, $\mathrm{pH} 8.0$, was also lowered into the LA. Coordinates for MGm/PIN were $-5.6 \mathrm{~mm} \mathrm{AP,} 2.9 \mathrm{~mm} \mathrm{ML}$, and -6.6 $\mathrm{mm}$ DV. Initial coordinates for the LA were $-3.2 \mathrm{~mm}$ AP, $5.5 \mathrm{~mm} \mathrm{ML}$, and $-6.0 \mathrm{~mm} \mathrm{DV}$. Final LA coordinates were optimized with the stimulation of MGm/PIN. Field-evoked responses in the LA were digitized using a CED Micro 1401 interface and Spike 2 software (Cambridge Electronic Design, Cambridge, UK). Stimulation intensities ranged from 100 to $400 \mu \mathrm{A}$ and were always $100 \mu \mathrm{s}$. For each experiment, a test intensity was chosen that evoked a field potential that was approximately one-half of its maximal amplitude. Baseline responses were recorded at $0.03 \mathrm{~Hz}$. Before LTP, rats were given an intrathalamic infusion of vehicle $(50 \% \mathrm{DMSO} ; 0.5 \mu \mathrm{l})$ or an equivalent volume of $\mathrm{U} 0126(1 \mu \mathrm{g})$ at a rate of $0.05 \mu \mathrm{l} / \mathrm{min}$. Baseline field responses were again recorded for $30 \mathrm{~min}$ before LTP induction. For LTP, we used a protocol consisting of presentation of three series of theta-patterned $100 \mathrm{~Hz}$ tetani at test intensity (Yaniv et al., 2001; Doyère et al., 2003). For auditory stimulation, we presented three series of 60 presentations of $5 \mathrm{kHz}, 50 \mathrm{~ms}, 85 \mathrm{~dB}$ tone pips (1 pip/s) immediately before and $30 \mathrm{~min}$ after drug infusion into MGm/ PIN. Each series of 60 pips was separated by $5 \mathrm{~min}$. Auditory-evoked responses in MGm/PIN were recorded through the tip of the stimulation electrode. Pips were delivered through a speaker attached to the right hollow ear bar on the stereotaxic frame.

At the end of each electrophysiological experiment, iontophoresis was used to deposit a small amount of pontamine sky blue into the LA to mark the recording site. Rats were then perfused, and brains were sectioned and stained with Nissl for analysis of electrode placement. For analysis of stimulation-evoked potentials, we used Spike 2 to analyze the amplitude of the short-latency ( $\sim 5-7 \mathrm{~ms})$ negative-going component of the evoked field potential from the initial point of deflection to its maximal negativity. For analysis of auditory-evoked potentials, all 60 potentials were averaged into a single waveform, and Spike2 was used to measure the amplitude of the P1 and N1 components (for details, see Fig. 6). Data were analyzed using Student's $t$ tests or ANOVA.

\section{Results}

\section{Inhibition of ERK/MAP kinase in the auditory thalamus before training impairs memory consolidation of auditory fear conditioning}

Previous studies have shown that synaptic plasticity and fear memory consolidation in the LA require the activation of the ERK/MAP kinase signaling pathway (Huang et al., 2000; Schafe et al., 2000); inhibition of ERK/MAPK in the LA impairs long-term memory (LTM) but not short-term memory (STM). Here, we investigated the role of ERK/MAP kinase 
activation in the auditory thalamus, using both multiple- and single-trial learning paradigms.

\section{Multiple-trial learning}

In the first experiment, rats were infused with different doses of U0126, a specific inhibitor of MEK, an upstream regulator of ERK/MAP kinase activation (Favata et al., 1998). Rats received bilateral intraMGm/PIN infusions of U0126 ( 1 or 0.1 $\mu \mathrm{g} / \mathrm{side}$ ) or vehicle $30 \mathrm{~min}$ before five tone shock pairings and were tested for the retention of tone memory at different time points after fear conditioning $(1,3,6$, and $24 \mathrm{~h}$ ) (Fig. 1a). The 1, 3, and 6 h memory tests each consisted of three trials each, whereas the $24 \mathrm{~h}$ test consisted of 10 tone presentations.

The results of the multiple-trial conditioning are shown in Figure 1. Infusions of U0126 did not affect postshock freezing (Fig. 1c), indicating that the drug did not affect sensitivity to the footshock. The effect for group $\left(F_{(2,24)}=1.11\right)$ and interaction $\left(F_{(18,216)}=1.21\right)$ were nonsignificant. There was only a significant effect of trial $\left(F_{(9,216)}=6.43 ; p<0.01\right)$. Similar to the effects of U0126 in the LA with multipletrial learning, STM measured at both 1 and $3 \mathrm{~h}$ after conditioning was intact relative to vehicle controls (Fig. 1d,e). The ANOVA for the $1 \mathrm{~h}$ test showed no significant effects $\left(F_{(2,24)}=1.24 ; p>0.05\right)$, as did the ANOVA for the $3 \mathrm{~h}$ test $\left(F_{(2,24)}=3.40 ; p>0.05\right)$. Both U0126 dose groups also showed intact memory at $6 \mathrm{~h}\left(F_{(2,24)}=3.27 ; p>0.05\right)$ (Fig. $\left.1 f\right)$.

At $24 \mathrm{~h}$, however, there was a pronounced effect of the highest dose of U0126. The ANOVA for the $24 \mathrm{~h}$ retention test showed a significant effect $\left(F_{(2,24)}=12.54 ; p<0.01\right)$ (Fig. $\left.1 g\right)$. Post hoc $t$ tests showed that the effect was produced by the highest dose of U0126, which was significantly different from both vehicle controls and the low-dose group $(p<0.05)$. There was no difference between vehicle controls and the lowest dose group $(p>0.05)$. Thus, intrathalamic infusion of U0126 impairs fear memory at $24 \mathrm{~h}$ but has no effect shortly after training. This pattern of findings is consistent with the conclusion that fear memory consolidation requires ERK/MAPK signaling in the auditory thalamus.

Because each animal in the previous experiment was tested in each memory test, it could be argued that the effect of U0126 observed at $24 \mathrm{~h}$ is attributable to facilitated extinction rather than impaired memory consolidation. To test for this possibility, we gave additional rats pretraining infusions of the highest dose of U0126 or vehicle, trained them using the same five trial training paradigm, and tested the animals $24 \mathrm{~h}$ later without the insertion of STM tests between conditioning and LTM testing (data not shown). Consistent with the previous experiment, the findings showed that intrathalamic infusion of U0126 impaired LTM formation $\left(t_{(9)}=3.95 ; p<0.01\right)$. Vehicle controls $(n=4)$ exhibited $87.3 \pm 4.3 \%$ freezing, whereas animals treated with U0126 $(n=7)$ showed $54.6 \pm 5.2 \%$ freezing.

\section{Single-trial learning}

In the previous experiments, memory was not affected shortly after training, suggesting that infusion of U0126 into the auditory thalamus did not affect sensory processing in the MGm/PIN or 0.05 relative to vehicle (Veh)
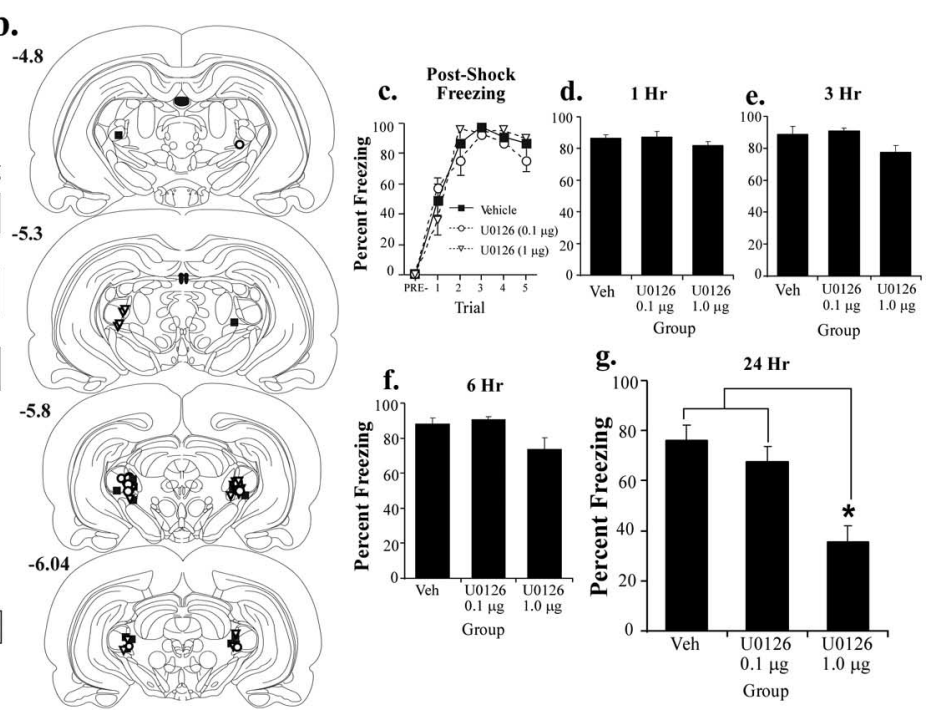

Grou

Figure 1. Effects of pretraining intrathalamic infusion of U0126 on multiple-trial fear conditioning. $\boldsymbol{a}$, Schematic of the behavioral protocol. Rats were given an intrathalamic infusion of 50\% DMSO vehicle $(n=9)$ or one of two doses of U0126 (1.0 or 0.1 $\mu \mathrm{g} / \mathrm{side} ; n=11$ and 7, respectively) 30 min before five tone-shock pairings. They were then tested for retention of auditory fear

transmission of that information to the LA. However, it might be argued that the use of the strong multiple-trial training paradigm obscured more subtle effects of thalamic manipulations on either CS or US processing in the MGm/PIN or its targets. To address this issue, we gave a separate group of animals intrathalamic infusions of the highest dose of U0126 and conditioned them using a weak training paradigm consisting of a single tone-shock pairing (Fig. 2a). Infusions were given $30 \mathrm{~min}$ before conditioning, and auditory fear retention was tested at both $1 \mathrm{~h}$ (STM) and $24 \mathrm{~h}$ (LTM). Here, each memory test consisted of 10 tone presentations.

The results of the single-trial learning experiment are shown in Figure $2 c-f$. As before, the drug infusions had no effect on postshock freezing, indicating that the drug did not disrupt footshock sensitivity (Fig. 2c). The ANOVA showed only a significant effect of trial $\left(F_{(1.16)}=177.89 ; p<0.01\right)$. The effect for group was not significant $\left(F_{(1,16)}=0.09\right)$. Also as before, memory was intact in U0126-treated animals $1 \mathrm{~h}$ after conditioning $\left(t_{(16)}=0.10 ; p>\right.$ 0.05 ) (Fig. $2 d$ ). Twenty-four hours later, however, rats infused with U0126 showed a significant impairment of LTM $t_{(16)}=$ 6.32; $p<0.01$ ) (Fig. 2e). Thus, even after weak training, inhibition of ERK/MAP kinase in the auditory thalamus impairs LTM but does not impair STM formation. This pattern of results indicates that intrathalamic infusion of U0126 is unlikely to have produced its effects on fear memory by disrupting sensory transmission in either the thalamus or its targets. Rather, ERK inhibition in the auditory thalamus appears to have a specific effect on memory consolidation.

As a final test of the specificity of intrathalamic U0126 on memory formation, we reconditioned the animals from the single-trial learning experiment $\sim 1$ week later to rule out the possibility that U0126 might impair memory by damaging the auditory thalamus. Both groups (vehicle and drug) were reconditioned drug free. The 

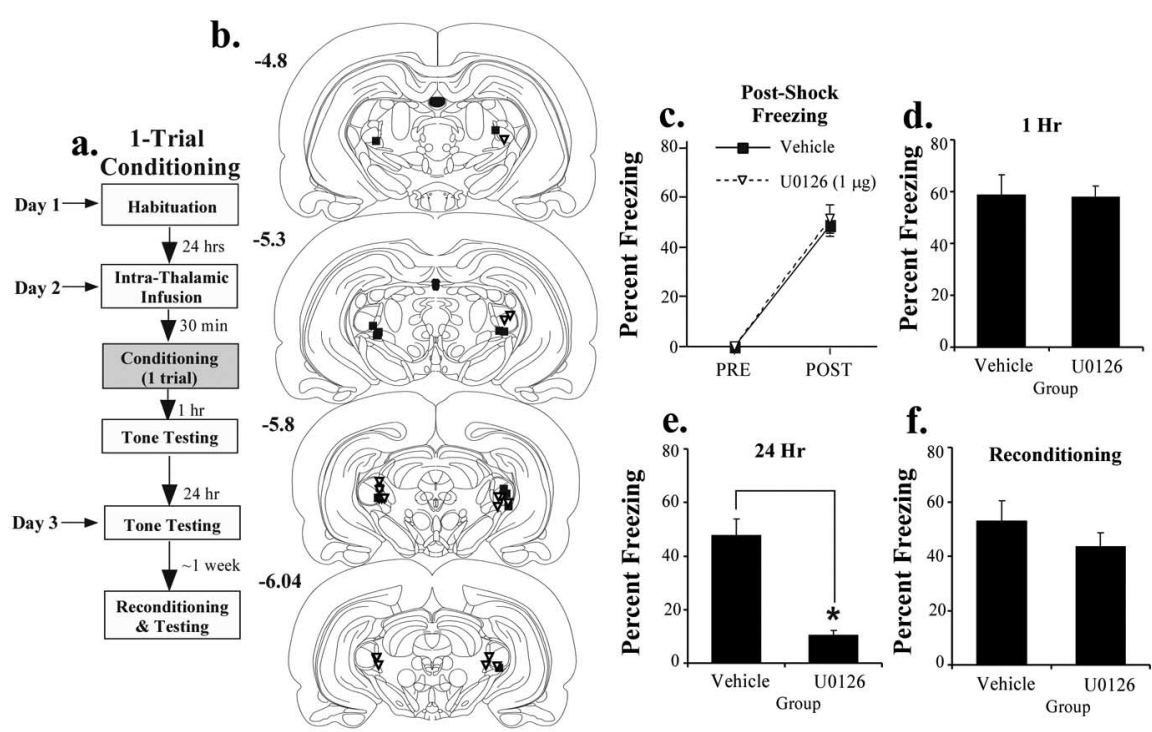

Figure 2. Effects of pretraining intrathalamic infusion of U0126 on single-trial fear conditioning. $\boldsymbol{a}$, Schematic of the behavioral protocol. Rats were given an intrathalamic infusion of 50\% DMSO vehicle $(n=8)$ or the highest dose of U0126 $(1.0 \mu \mathrm{g} / \mathrm{side} ; n=$ 10) $30 \mathrm{~min}$ before one tone-shock pairing. They were then tested for retention of auditory fear conditioning 1 and $24 \mathrm{~h}$ after conditioning. $\boldsymbol{b}$, Cannula placements in rats given an intrathalamic infusion of 50\% DMSO vehicle (black squares) or U0126 (white triangles). $c$, Mean \pm SE postshock freezing after the conditioning trial in rats given an intrathalamic infusion of $50 \%$ DMSO (black squares) or U0126 (white triangles). $\boldsymbol{d}$, Mean \pm SE auditory fear memory assessed at $1 \mathrm{~h}$ after conditioning in the rats from c.e Mean \pm SE auditory fear memory assessed at $24 \mathrm{~h}$ after conditioning in the rats from c.f, Mean \pm SE auditory fear memory after reconditioning $\sim 1$ week later. ${ }^{*} p<0.05$ relative to vehicle.

results, shown in Figure $2 f$, show that the U0126-treated group had no problem reacquiring conditioned fear $\left(t_{(16)}=1.07 ; p>0.05\right)$. Thus, the memory deficits observed in U016-treated rats cannot be attributable to nonspecific damage to the auditory thalamus.

\section{Histology}

Histological verification of cannula placements is shown in Figure $1 b$ for multiple-trial learning and Figure $2 b$ for single-trial learning. The cannula tips were positioned throughout the $\mathrm{MGm} / \mathrm{PIN}$ at different rostrocaudal levels. Only rats with correct bilateral placements were included in the data analysis.

\section{Intrathalamic inhibition of ERK/MAP kinase or mRNA synthesis, but not protein synthesis, immediately after training impairs memory consolidation of auditory fear conditioning}

In the previous set of experiments, pretraining infusion of an ERK/MAP kinase inhibitor impaired LTM, but not STM, of auditory fear conditioning. These findings suggest that ERKdependent plasticity in the MGm/PIN contributes to fear memory consolidation. In the second series of experiments, we directly tested this hypothesis by examining the effects of immediate posttraining intrathalamic infusion of U0126 on fear memory formation. In addition, we included groups that received intrathalamic infusion of the protein synthesis inhibitor anisomycin $(62.5 \mu \mathrm{g} / \mathrm{side})$ or the mRNA synthesis inhibitor DRB (18 $\mathrm{ng} / \mathrm{side}$ ). Each of these latter compounds has been shown to impair synaptic plasticity and memory consolidation of fear conditioning when infused into the LA, presumably by interfering with processes that are essential for long-term plasticity and memory storage (Huang et al., 2000; Schafe et al., 2000; Schafe and LeDoux, 2000) (S. Duvarci, K. Nader, and J. E. LeDoux, unpublished observations).

The behavioral protocol for the posttraining experiment is presented in Figure $3 a$. Rats were conditioned with a single tone-

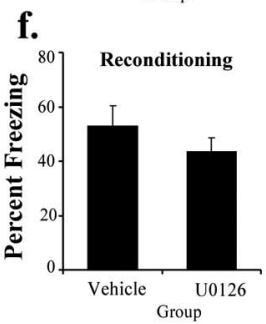

shock pairing, infused, and tested $24 \mathrm{~h}$ later with 10 tone presentations. The findings are presented in Figure 3, $c$ and $d$. Just before infusion of each compound, each group of rats acquired equivalent amounts of fear as indicated by postshock freezing (Fig. $3 c$ ). The ANOVA showed only a significant effect of trial $\left(F_{(1,31)}=454.9 ; p<\right.$ $0.01)$ but not of group $\left(F_{(3,31)}=0.72\right)$. As with pretraining infusions, immediate posttraining infusion of U0126 significantly impaired memory consolidation, as did infusion of DRB (Fig. 3d). Posttraining infusion of anisomycin, however, had no effect. The overall ANOVA for all groups showed a significant effect $\left(F_{(3,31)}=6.34\right.$; $p<0.01)$. Post hoc $t$ tests showed that both the U0126- and DRB-treated groups were significantly different from vehicle controls and the anisomycin-infused group $(p<0.05)$. The anisomycin-infused group was not significantly different from vehicle-treated animals $(p>0.05)$.

In our initial experiments, we used the dose of anisomycin that has been shown to impair fear memory consolidation when infused into the LA (Schafe and LeDoux, 2000). To rule out the possibility that a higher dose of anisomycin is required in the auditory thalamus to impair fear memory consolidation, we infused a separate group of rats with twice the dose of anisomycin (125 $\mu \mathrm{g} / \mathrm{side}$; data not shown). The findings revealed that this higher dose was also ineffective at impairing fear conditioning $\left(t_{(15)}=0.25 ; p>0.05\right)$. The vehicle-treated group $(n=10)$ showed $67.15 \pm 7.44 \%$ freezing, whereas the group treated with the high dose of anisomycin $(n=7)$ showed $69.7 \pm 5.1 \%$ freezing. Thus, inhibition of ERK/MAP kinase and of mRNA synthesis, but not of protein synthesis, in the auditory thalamus impairs fear memory consolidation.

\section{Histology}

Histological verification of cannula placements for the posttraining infusions is shown in Figure $3 b$. The cannula tips were positioned throughout the $\mathrm{MGm} / \mathrm{PIN}$ at different rostrocaudal levels. Only rats with correct bilateral placements in the MGm/PIN were included in the data analysis.

\section{Intrathalamic inhibition of ERK/MAP kinase has no effect on} retrieval or reconsolidation of auditory fear conditioning

Recent studies have shown that fear memories, when reactivated or retrieved, return to a labile state in the LA and require protein synthesis for reconsolidation (Nader et al., 2000; Duvarci and Nader, 2004). To determine whether the auditory thalamus might also participate in this reconsolidation process, we infused U0126 into the MGm/PIN before reactivation of an auditory fear memory. In our initial experiments, we used the same dose of U0126 that was effective at impairing consolidation. The protocol for this experiment is described in Figure $4 a$. Rats were habituated and conditioned drug free. On the next day, they were infused with either vehicle or U0126 ( $1 \mu \mathrm{g} / \mathrm{side}) 30 \mathrm{~min}$ before a single reactivation (retrieval) test. To examine the effects of intrathalamic blockade of ERK/MAP kinase on subsequent retention of conditioned fear, rats were then tested for retention of 


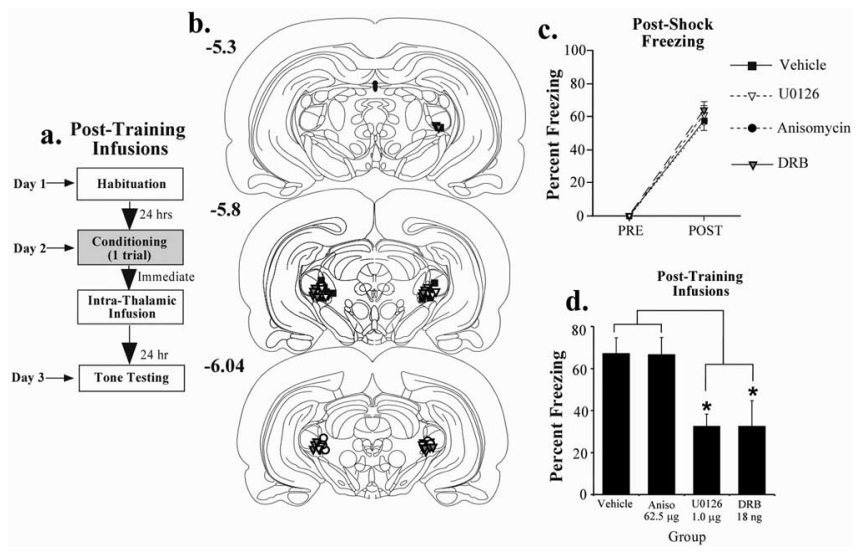

Figure 3. Effects of immediate posttraining intrathalamic infusion of U0126, anisomycin, or DRB. $\boldsymbol{a}$, Schematic of the behavioral protocol. Rats were given a single tone-shock pairing and then given an immediate intrathalamic infusion of $50 \%$ DMSO vehicle $(n=10)$, the highest dose of U0126 (1.0 $\mu \mathrm{g} / \mathrm{side} ; n=9)$, the protein synthesis inhibitor anisomycin (62.5 $\mu \mathrm{g} / \mathrm{side}$; $n=10)$, or the mRNA synthesis inhibitor DRB ( $16 \mathrm{ng} / \mathrm{side} ; n=7)$. They were then tested for retention of auditory fear conditioning $24 \mathrm{~h}$ after conditioning. $\boldsymbol{b}$, Cannula placements in rats given an intrathalamic infusion of 50\% DMSO (vehicle; black squares), U0126 (white triangles), anisomycin (black circles), or DRB (gray triangles). c, Mean \pm SE postshock freezing after the conditioning trial in rats given an intrathalamic infusion of 50\% DMSO (black squares), U0126 (white triangles), anisomycin (black circles), or DRB (gray triangles).d, Mean \pm SE auditory fear memory assessed at $24 \mathrm{~h}$ after conditioning in the rats from $c$. Aniso, Anisomycin. ${ }^{*} p<0.05$ relative to vehicle.

auditory fear conditioning at 3 and $24 \mathrm{~h}$ after the reactivation trial ( 3 and 10 tone presentations, respectively). To keep consistent with previous terminology (Nader et al., 2000), we refer here to the $3 \mathrm{~h}$ test as post-reactivation STM (PR-STM) and the $24 \mathrm{~h}$ test as post-reactivation LTM (PR-LTM).

The findings revealed that intrathalamic infusion of U0126 impaired neither retrieval nor reconsolidation of auditory fear conditioning. Rats in each group conditioned normally, as evidenced by postshock freezing (Fig. $4 c$ ). The ANOVA for postshock freezing scores showed only a significant effect for trials $\left(F_{(1,16)}=255.0 ; p<0.01\right)$. The effect for group was not significant $\left(F_{(1,26)}=0.005\right)$. Furthermore, on the following day, both vehicle and U0126-infused groups showed equivalent retrieval of the fear memory during the reactivation trial $\left(t_{(16)}=0.11 ; p>\right.$ 0.05 ) (Fig. $4 d$ ). Fear memory was also intact on subsequent retrieval tests (Fig. 4e,f). There was no significant difference between vehicle and U0126-treated rats in either the $3 \mathrm{~h}$ test $\left(t_{(16)}=\right.$ $0.28 ; p>0.05)$ or the $24 \mathrm{~h}$ test $\left(t_{(16)}=0.61 ; p>0.05\right)$. Importantly, these findings provide an additional series of controls for the consolidation experiments, indicating that ERK inhibition in the thalamus does not interfere with auditory processing in the thalamus or its targets. Furthermore, the fact that memory remained intact $24 \mathrm{~h}$ later suggests that intrathalamic infusion of U0126 did not produce memory deficits in the consolidation experiments by somehow nonspecifically competing with freezing $24 \mathrm{~h}$ after infusion.

To further examine the null effect of intrathalamic infusion of U0126 on reconsolidation, we infused twice the amount of U0126 ( $2 \mu \mathrm{g} /$ side) into a separate group of rats before reactivation $(n=7$; data not shown). As before, there was no significant effect on reactivation (vehicle, $68.8 \pm 9.1$; drug, $67.1 \pm 6.0 ; t_{(14)}=$ $0.14 ; p>0.05$ ), PR-STM (vehicle, $65.5 \pm 10.2$; drug, $70 \pm 6.46$; $t_{(14)}=0.33 ; p>0.05$ ), or PR-LTM (vehicle, $40.1 \pm 8.3$; drug, $\left.43 \pm 8.7 ; t_{(14)}=0.23 ; p>0.05\right)$. Thus, although ERK/MAP inhibition in the auditory thalamus impairs memory consolida- tion, it does not appear to affect reconsolidation. Importantly, these data are consistent with those of a recent study, in which we showed that intra-amygdala infusion of a nitric oxide synthase (NOS) inhibitor or a membrane-impermeable scavenger of nitric oxide (NO) impaired consolidation, but not reconsolidation, of auditory fear conditioning (Schafe et al., 2005). Collectively, this pattern of findings might suggest that the reconsolidation process is exclusively postsynaptic, whereas initial memory formation and consolidation involves plasticity at both sides of the synapse.

\section{Histology}

Histological verification of cannula placements for the reconsolidation experiment is shown in Figure $4 b$. The cannula tips were positioned throughout the $\mathrm{MGm} / \mathrm{PIN}$ at different rostrocaudal levels. Only rats with both cannula tips in the MGm/PIN were included in the data analysis.

\section{Intrathalamic inhibition of ERK/MAP kinase impairs long-term potentiation in the lateral amygdala}

The findings of our previous experiments indicate that intrathalamic infusion of an inhibitor of ERK/MAP kinase or mRNA synthesis, but not of protein synthesis, impairs memory consolidation of auditory fear conditioning. Collectively, these findings are consistent with the possibility that the auditory thalamus contributes to fear memory formation but is not itself a site of protein synthesis-dependent memory storage. One possibility is that ERK/MAPK signaling in the MGm/PIN contributes to presynaptic aspects of synaptic plasticity in the LA (Maren and Fanselow, 1995). As a test of this hypothesis, we ran in vivo electrophysiology experiments in which LTP was induced in the LA 30 min after intrathalamic infusion of 50\% DMSO vehicle or U0126 (1 $\mu \mathrm{g})$. Infusions were made through a stainless-steel cannula attached to the insulated stimulation electrode (Fig. $5 a$ ). The protocol for each LTP experiment is described in Figure $5 b$ (for additional details, see Materials and Methods). Stimulation-evoked baseline responses were recorded in the LA for $1 \mathrm{~h}$, followed by intrathalamic infusion of either vehicle or U0126. After infusion, baseline responses were recorded for an additional $30 \mathrm{~min}$, after which LTP was induced in the LA. For analysis, responses across this second baseline were averaged into a single score for each rat. After LTP induction, we recorded a third stimulation-evoked baseline for an additional $3 \mathrm{~h}$. For analysis, this final recording period was binned into 5 min intervals and compared with responses recorded during the last $15 \mathrm{~min}$ of the pre-LTP baseline.

Results of the LTP experiment are presented Figure 5, $d$ and $e$. Intrathalamic infusion of vehicle and drug solutions produced a modest reduction $(10-15 \%)$ in the amplitude of field-evoked responses in the LA, but there was no significant difference between vehicle and U0126-treated rats $\left(t_{(9)}=0.49 ; p>0.05\right)$. However, LTP at thalamic inputs to the LA was significantly impaired by U0126. The overall ANOVA (drug by time) for percentage change in evoked responses in LA after LTP induction showed a significant effect of group $\left(F_{(1,9)}=5.40 ; p<0.05\right)$ and time $\left(F_{(35,315)}=2.18 ; p<0.01\right)$ but no significant interaction $\left(F_{(35,315)}=0.29\right)$. Within the last hour of the recording session, the vehicle group showed $21 \pm 8 \%$ increase in field potential amplitude, which was significantly different from baseline $\left(t_{(4)}=\right.$ 2.54; $p<0.05)$. In contrast, rats infused with U0126 showed $1.52 \pm 4.3 \%$ potentiation, which was not significantly different from baseline $\left(t_{(5)}=0.36 ; p>0.05\right)$. Thus, intrathalamic infusions of U0126 at the dose that impairs fear memory consolidation also impairs synaptic plasticity in the LA.

As one final test of whether U0126 impairs sensory processing 

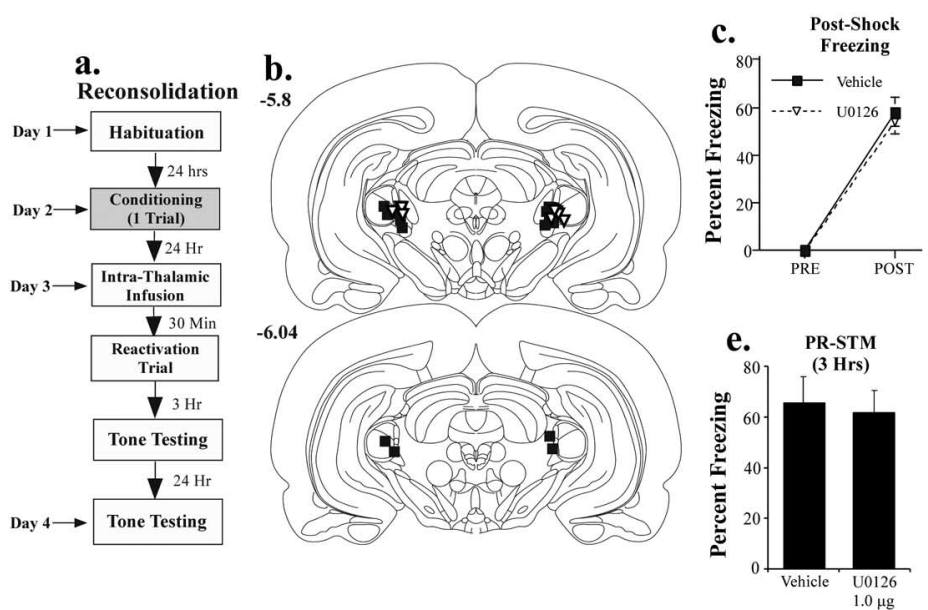

Figure 4. Effects of intrathalamic infusion of U0126 on retrieval and reconsolidation of auditory fear conditioning. $a$, Schematic of reconsolidation behavioral protocol. Rats were trained with one tone-shock pairing. Twenty-four hours later, they received an intrathalamic infusion of 50\% DMSO vehicle $(n=9)$ or the highest dose of U0126 $(1 \mu \mathrm{g} ; n=9) 30$ min before a single tone retention (reactivation) test. They were then tested for retention of auditory fear conditioning at 3 and $24 \mathrm{~h}$ after the reactivation test. $\boldsymbol{b}$, Cannula placements in rats given an intrathalamic infusion of 50\% DMSO (vehicle; black squares) or U0126 (white triangles).c, Mean \pm SE postshock freezing after the conditioning trial in vehicle controls (black squares) and U0126-treated rats (white triangles). $\boldsymbol{d}$, Mean \pm SE auditory fear memory assessed during the reactivation trial $\sim 24 \mathrm{~h}$ after training. $\boldsymbol{e}$, Mean \pm SE auditory fear memory assessed at $1 \mathrm{~h}$ after the reactivation trial (PR-STM). $f$, Mean \pm SE auditory fear memory assessed at $24 \mathrm{~h}$ after the reactivation trial (PR-LTM).

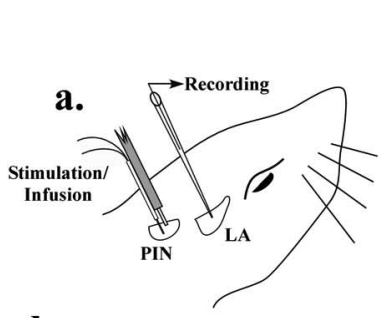

b.

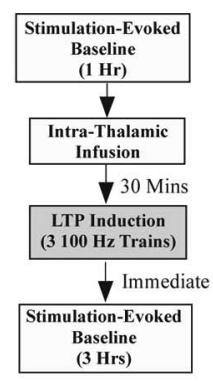

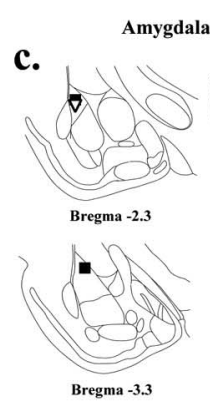

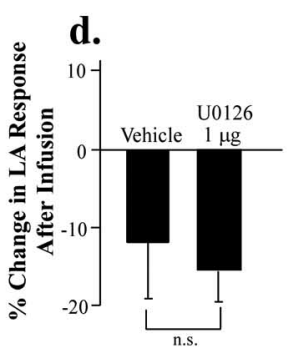

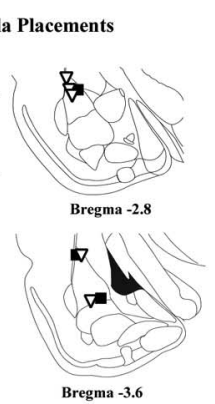
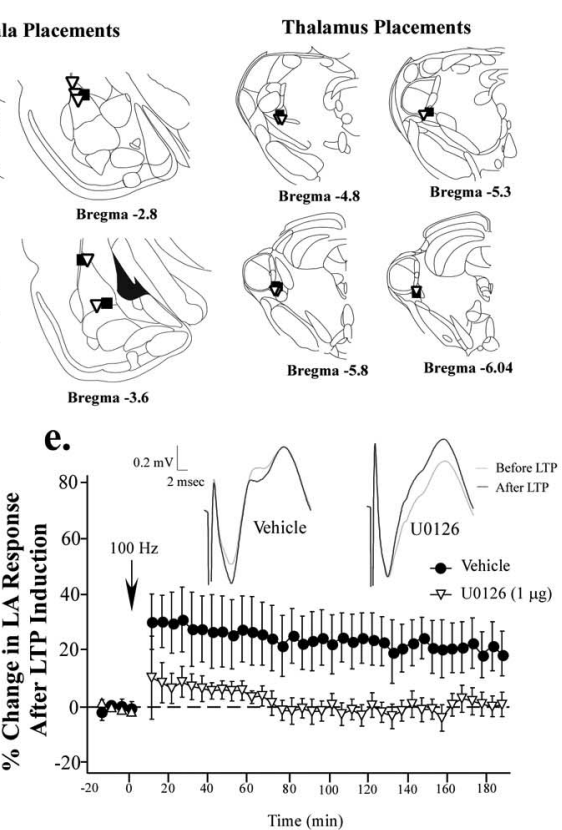

Figure 5. Effects of intrathalamic infusion of U0126 on long-term potentiation in the LA. $\boldsymbol{a}$, Illustration of cannula and electrode implantation. Rats were implanted with a glass recording pipette into the $L A$ and a stimulation electrode into the MGm/PIN that was adhered to a stainless-steel infusion cannula. $\boldsymbol{b}$, Schematic of experimental protocol. Rats received an infusion of $50 \%$ DMSO vehicle $(n=5)$ or U0126 (1.0 $\mu \mathrm{g} ; n=6) 30$ min before LTP-inducing stimulation of the auditory thalamus. Baseline recordings were taken before and after the infusion, as well as after LTP induction (see Materials and Methods). c, Electrode placements in the LA and MGm/PIN in vehicle controls (black squares) and U0126-treated rats (white triangles). $\boldsymbol{d}$, Effects of intrathalamic infusion of 50\% DMSO vehicle and U0126 on baseline synaptic transmission in the LA. e, Effects of intrathalamic infusion of 50\% DMSO vehicle (black circles) and U0126 (white triangles) on LTP in the LA. Data are expressed as percentage change (relative to baseline) in the amplitude of the field-evoked response in the LA over the $3 \mathrm{~h}$ recording period. Representative traces for vehicle and U0126-treated rats before and after LTP are presented in the inset.

in the auditory thalamus, we took advantage of our electrophysiological experiments to examine the effect of U0126 on auditory-evoked responses in the MGm/PIN. Auditory-evoked field potentials were evoked in the MGm/PIN by presentation of
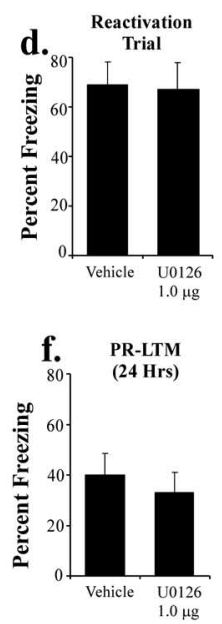

$5 \mathrm{kHz}, 50 \mathrm{~ms}$ tone pips ( $1 \mathrm{~Hz}$; 60 presentations) before and $30 \mathrm{~min}$ after the infusion of U0126 and recorded through the stimulation electrode. As depicted in Figure $6 a$, these potentials are characterized by a short-latency positive component (P1), as well as a negative component (N1) that correspond to spikes elicited by the tone. We analyzed both components before and after infusion and found no significant effects of U0126 on either (Fig. 6b). The ANOVA showed a nonsignificant effect for group for the positive component $\left(F_{(1,6)}=\right.$ $0.02 ; p>0.05)$, as well as the negative component $\left(F_{(1,6)}=0.60 ; p>0.05\right)$. Thus, intrathalamic infusion of U0126 at the dose that is effective at impairing fear conditioning does not appear to affect auditory processing in the MGm/PIN.

\section{Discussion}

The present experiments were aimed at determining how the auditory thalamus might contribute to fear memory formation. We examined the role of ERK/MAPK signaling, mRNA, and protein synthesis, which are all known to be required for long-term synaptic plasticity and memory formation in the LA and in other memory systems (Milner et al., 1998; Maren, 2001; Schafe et al., 2001; Rodrigues et al., 2004; Sweatt, 2004). Our findings revealed that the $\mathrm{MGm} / \mathrm{PIN}$ does indeed participate in fear memory formation but in ways more complex than originally anticipated. Intrathalamic infusion of either an ERK/ MAPK or mRNA synthesis inhibitor impaired fear memory formation. However, infusion of the protein synthesis inhibitor anisomycin had no effect. The latter finding is consistent with a recently published report by Maren et al. (2003) and suggests that the auditory thalamus, although necessary for fear conditioning, is not itself a site of protein synthesis-dependent memory storage.

How might the auditory thalamus contribute to the consolidation of fear conditioning if not via local protein synthesisdependent changes in the MGm/PIN? One possibility is that ERK-mediated transcriptional changes in the MGm/PIN might be essential for presynaptic aspects of plasticity and memory formation in the LA. In support of this hypothesis, we showed that infusion of the ERK/MAPK inhibitor U0126 into the auditory thalamus impaired LTP at thalamic inputs to the LA. Together with the results of the behavioral experiments, these findings suggest a model in which fear conditioning and associated synaptic plasticity in the LA involves both a presynaptic and postsynaptic component. Con- 


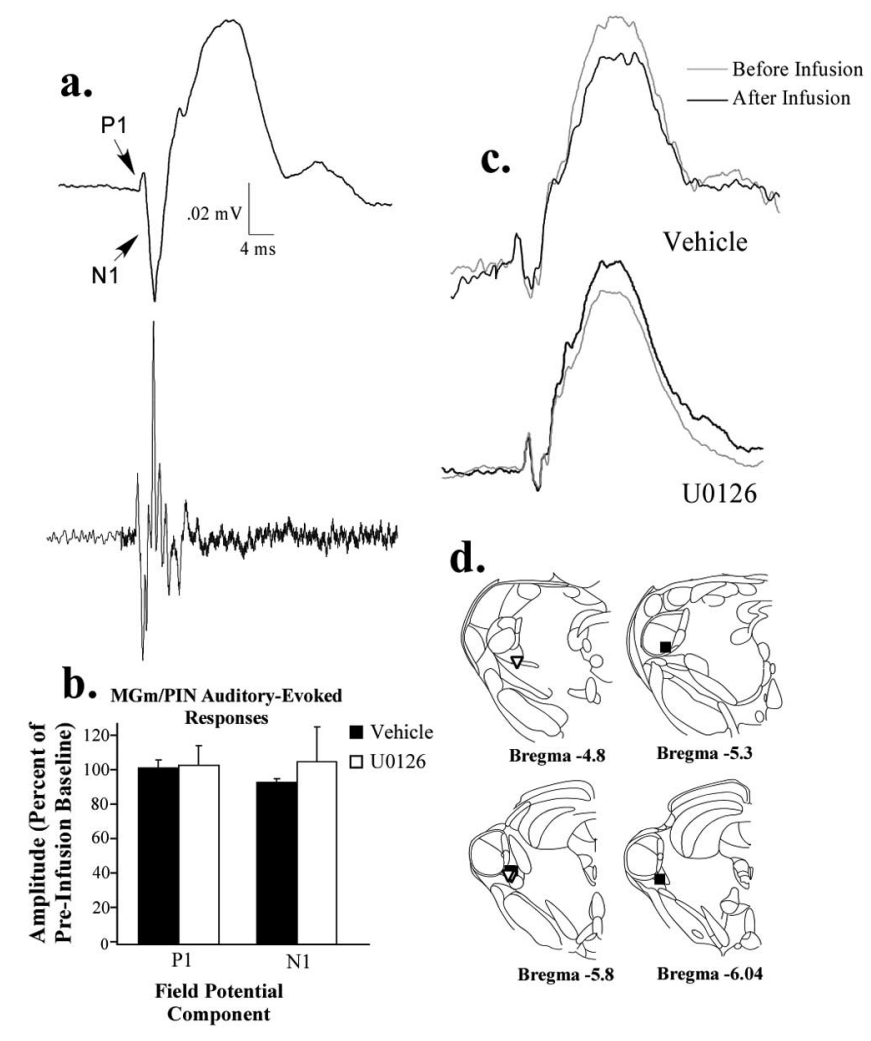

Figure 6. Effects of intrathalamic infusion of U0126 on auditory-evoked potentials in the MGm/PIN. $\boldsymbol{a}$, An auditory-evoked field potential in the MGm/PIN (top), averaged over many presentations of a $5 \mathrm{kHz}$, $50 \mathrm{~ms}$ tone pip. Note the initial positive-going (P1) and negative-going (N1) components of the field potential that correspond to the emergence of spiking in the multiunit recording (bottom). $\boldsymbol{b}$, Effect of intrathalamic infusion of U0126 (1 $\mu \mathrm{g})$ or $50 \%$ DMSO vehicle on P1 and N1 components of the auditory-evoked field potential in the MGm/PIN. C, Representative auditory-evoked field potentials in the MGm/PIN before and after infusion in both vehicle and U0126-treated animals. $\boldsymbol{d}$, Electrode placements in the MGm/PIN in both vehicle controls (black squares) and animals infused with U0126 (white triangles).

vergence of CS and US inputs in the LA during fear conditioning may engage not only NMDA receptor (NMDAR)-mediated postsynaptic alterations in protein kinase signaling, transcription, and protein synthesis (Bailey et al., 1999; Schafe and LeDoux, 2000; Schafe et al., 2000; Josselyn et al., 2001) but also presynaptic signaling pathways via retrograde signaling (Schafe et al., 2005). Downstream activation of the ERK/MAPK signaling pathway in presynaptic thalamic targets of LA neurons may then lead to transcriptional changes in MGm/PIN cells that are necessary to promote protein synthesis-dependent structural changes on the presynaptic side of LA synapses. Accordingly, infusion of ERK/MAPK or mRNA synthesis inhibitors into the MGm/PIN would be expected to impair fear conditioning, whereas infusion of protein synthesis inhibitors would have no effect. In contrast, infusion of a protein synthesis inhibitor into the LA would impair fear learning (Schafe and LeDoux, 2000; Maren et al., 2003), presumably by affecting both presynaptic and postsynaptic aspects of plasticity.

Ample evidence suggests that synaptic plasticity in both vertebrates and invertebrates involves both presynaptic and postsynaptic mechanisms (Bonhoeffer et al., 1989; Kullmann and Nicoll, 1992; Lisman and Harris, 1993; Roberts and Glanzman, 2003). In CA1 neurons of the hippocampus, in which LTP induction is known to require NMDAR-mediated elevations in $\mathrm{Ca}^{2+}$ in the postsynaptic cell (Malenka and Nicoll, 1993; Malenka and Nicoll, 1999), it has been estimated that as much as $60 \%$ of LTP mainte- nance depends on presynaptic enhancement (Liao et al., 1992). In support of this hypothesis, LTP in area CA1 is known to lead to increases in presynaptic vesicle mobilization and release (Arancio et al., 1995; Zakharenko et al., 2001), as well as structural changes in the presynaptic terminal (Toni et al., 2001; Nikonenko et al., 2003). In Aplysia, classical conditioning of the gill-withdrawal reflex has also been shown to depend on both presynaptic and postsynaptic associative mechanisms (Antonov et al., 2003; Roberts and Glanzman, 2003). There, conditioned enhancement of the gill-withdrawal response is thought to be initiated by NMDAR-mediated alterations in the (postsynaptic) motor neuron; conditioning is prevented by bath application of either APV to sensorimotor synapses or postsynaptic injection of the $\mathrm{Ca}^{2+}$ chelator BAPTA (Lin and Glanzman, 1994; Murphy and Glanzman, 1996; Murphy and Glanzman, 1997; Antonov et al., 2003). On the presynaptic side, however, alterations in the cAMP system are thought to promote long-term changes in cell excitability (Antonov et al., 2003), as well as structural changes (Bailey et al., 1992; Bailey and Kandel, 1993). Of interest to the present paper, Martin et al. (1997a) showed that long-term facilitation (LTF), a cellular analog of the classical conditioning of the gill-withdrawal reflex, depends on activation and nuclear translocation of ERK/ MAP kinase in the presynaptic sensory neuron (Martin et al., 1997a). Translocation of ERK to the nucleus of the presynaptic neuron, together with PKA, leads to cAMP response elementbinding protein-mediated transcription and the induction of multiple immediate early genes (Martin et al., 1997a,b; Casadio et al., 1999). The protein synthesis-dependent structural changes that underlie LTF, however, are thought to involve local translation of synaptically localized mRNA in the terminal endings of presynaptic neurons (Martin et al., 1997b; Casadio et al., 1999). Such a mechanism, which has also been proposed for hippocampal synaptic plasticity (Frey and Morris, 1997), accounts for how cell-wide changes in gene expression can lead to long-term, synapse-specific plasticity (Frey and Morris, 1997; Martin et al., 1997b). Whether fear conditioning leads to a similar nuclear translocation of ERK/MAPK in the auditory thalamus is a question that awaits additional study.

Inherent in our model of presynaptic change in fear conditioning is the assumption that local protein synthesis can occur in vertebrate axons and terminals. Most recent studies that have examined a possible role for localized structural plasticity in vertebrate neurons after LTP or learning have focused on translational mechanisms in dendrites and spines (Steward and Schuman, 2001; Lamprecht and LeDoux, 2004). However, there is also evidence that ribosomes are present in invertebrate as well as vertebrate axons (Giuditta et al., 2002). Furthermore, local axonal de novo protein synthesis is thought to play a crucial role in a variety of cellular processes ranging from axon guidance during development (Campbell and Holt, 2001; Zheng et al., 2001) to regeneration and sprouting after axonal injury (Tobias and Koenig, 1975; Gaete et al., 1998). Together with the evidence that local presynaptic protein synthesis is crucial for synaptic plasticity in Aplysia (Martin et al., 1997b; Casadio et al., 1999), this provides a way in which presynaptic protein synthesis in axons and/or terminals in the LA may contribute to fear memory formation. The question of whether fear conditioning induces presynaptic structural changes in the LA via locally regulated protein synthesis is an important one and will require additional investigation.

Recent evidence from our laboratory has suggested that NO signaling in the LA is critical to fear memory formation (Schafe et 
al., 2005) and may represent a mechanism whereby postsynaptic induction of plasticity induced by fear conditioning in LA neurons may engage accompanying presynaptic changes. In other memory systems, NO is thought to serve as a retrograde messenger that engages aspects of presynaptic plasticity (Schuman and Madison, 1991; Zhuo et al., 1994; Arancio et al., 1996; Doyle et al., 1996; Son et al., 1998; Ko and Kelly, 1999; Lu et al., 1999) and memory formation (Chapman et al., 1992; Bohme et al., 1993; Bernabeu et al., 1995; Holscher et al., 1996; Suzuki et al., 1996; Zou et al., 1998). In our recent experiments, we showed that paired-pulse facilitation was occluded by LTP at thalamic inputs to the LA and that bath application of either an NOS inhibitor or a membrane-impermeable scavenger of NO impaired LTP at thalamo-LA synapses. Furthermore, intra-amygdala infusion of both compounds impaired fear memory consolidation; that is, LTM was impaired, whereas STM was intact (Schafe et al., 2005). The question of whether extracellular signaling by NO might activate ERK/MAPK signaling in auditory thalamic neurons during fear conditioning has not yet been examined.

Although not explicitly tested here, the findings of the present study also leave open the possibility that ERK-mediated transcriptional changes in MGm/PIN neurons contribute to the longterm alteration in firing properties of these cells after fear conditioning. Recent studies in Aplysia, for example, have shown conditioning-induced alterations in the excitability of (presynaptic) sensory neurons are blocked by injection of BAPTA into the postsynaptic neuron (Antonov et al., 2003), suggesting that a postsynaptically generated transynaptic signal may be sufficient to drive intrinsic changes in presynaptic excitability. A similar finding has emerged in the hippocampus, in which correlated presynaptic and postsynaptic spiking has been shown to lead to long-term enhancements in intrinsic presynaptic neuronal excitability, presumably by lowering the spike threshold in presynaptic neurons (Ganguly et al., 2000). In our context, the change in excitability of MGm/PIN neurons after fear conditioning would be dependent on plastic changes initiated by NMDAR-mediated plasticity in LA neurons. Recent studies have supported such a notion; either lesions or functional inactivation of the LA have been shown to disrupt the establishment of plasticity in the MGm/PIN [Maren et al., 2001; Poremba and Gabriel, 2001 (although note that, in each of these studies, fear conditioning proceeded normally after reversal of LA inactivation without accompanying changes in MGm/PIN firing)]. Importantly, recent data suggest that intrinsic excitability can be modified in an inputspecific manner at the dendritic level (Daoudal and Debanne, 2003). A similar mechanism localized at the level of active afferents during presentation of the CS would allow a nonsynaptic but still highly specific long-term increase in firing to the CS in the auditory thalamus after conditioning, which could account for the frequency retuning that has been observed in MGm/PIN after fear conditioning (Edeline and Weinberger, 1992; Lennartz and Weinberger, 1992).

In conclusion, the results of the present study suggest that ERK-mediated transcription in the auditory thalamus underlies fear memory consolidation and synaptic plasticity in the LA. These findings provide a potential biochemical mechanism whereby thalamic neurons might contribute to presynaptic aspects of plasticity during fear conditioning and make an additional contribution toward understanding the cellular and molecular processes underlying emotional memory formation in the mammalian brain.

\section{References}

Antonov I, Antonova I, Kandel ER, Hawkins RD (2003) Activity-dependent presynaptic facilitation and hebbian LTP are both required and interact during classical conditioning in Aplysia. Neuron 37:135-147.

Arancio O, Kandel ER, Hawkins RD (1995) Activity-dependent long-term enhancement of transmitter release by presynaptic $3^{\prime}, 5^{\prime}$-cyclic GMP in cultured hippocampal neurons. Nature 376:74-80.

Arancio O, Kiebler M, Lee CJ, Lev-Ram V, Tsien RY, Kandel ER, Hawkins RD (1996) Nitric oxide acts directly in the presynaptic neuron to produce long-term potentiation in cultured hippocampal neurons. Cell 87:1025-1035.

Bailey CH, Kandel ER (1993) Structural changes accompanying memory storage. Annu Rev Physiol 55:397-426.

Bailey CH, Montarolo P, Chen M, Kandel ER, Schacher S (1992) Inhibitors of protein and RNA synthesis block structural changes that accompany long-term heterosynaptic plasticity in Aplysia. Neuron 9:749-758.

Bailey DJ, Kim JJ, Sun W, Thompson RF, Helmstetter FJ (1999) Acquisition of fear conditioning in rats requires the synthesis of mRNA in the amygdala. Behav Neurosci 113:276-282.

Bernabeu R, de Stein ML, Fin C, Izquierdo I, Medina JH (1995) Role of hippocampal NO in the acquisition and consolidation of inhibitory avoidance learning. NeuroReport 6:1498-1500.

Birt D, Olds M (1981) Associative response changes in lateral midbrain tegmentum and medial geniculate during differential appetitive conditioning. J Neurophysiol 46:1039-1055.

Blair HT, Schafe GE, Bauer EP, Rodrigues SM, LeDoux JE (2001) Synaptic plasticity in the lateral amygdala: a cellular hypothesis of fear conditioning. Learn Mem 8:229-242.

Blanchard RJ, Blanchard DC (1969) Crouching as an index of fear. J Comp Physiol Psychol 67:370-375.

Bohme GA, Bon C, Lemaire M, Reibaud M, Piot O, Stutzmann JM, Doble A, Blanchard JC (1993) Altered synaptic plasticity and memory formation in nitric oxide synthase inhibitor-treated rats. Proc Natl Acad Sci USA 90:9191-9194.

Bonhoeffer T, Staiger V, Aertsen A (1989) Synaptic plasticity in rat hippocampal slice cultures: local "Hebbian" conjunction of pre- and postsynaptic stimulation leads to distributed synaptic enhancement. Proc Natl Acad Sci USA 86:8113-8117.

Campbell DS, Holt CE (2001) Chemotropic responses of retinal growth cones mediated by rapid local protein synthesis and degradation. Neuron 32:1013-1026.

Casadio A, Martin KC, Giustetto M, Zhu H, Chen M, Bartsch D, Bailey CH, Kandel ER (1999) A transient, neuron-wide form of CREB-mediated long-term facilitation can be stabilized at specific synapses by local protein synthesis. Cell 99:221-237.

Chapman PF, Atkins CM, Allen MT, Haley JE, Steinmetz JE (1992) Inhibition of nitric oxide synthesis impairs two different forms of learning. NeuroReport 3:567-570.

Daoudal G, Debanne D (2003) Long-term plasticity of intrinsic excitability: learning rules and mechanisms. Learn Mem 10:456-465.

Davis M, Walker DL, Lee Y (1997) Roles of the amygdala and bed nucleus of the stria terminalis in fear and anxiety measured with the acoustic startle reflex. Possible relevance to PTSD. Ann NY Acad Sci 821:305-331.

Doron NN, Ledoux JE (1999) Organization of projections to the lateral amygdala from auditory and visual areas of the thalamus in the rat. J Comp Neurol 412:383-409.

Doyère V, Schafe GE, Sigurdsson T, LeDoux JE (2003) Long-term potentiation in freely moving rats reveals asymmetries in thalamic and cortical inputs to the lateral amygdala. Eur J Neurosci 17:2703-2715.

Doyle C, Holscher C, Rowan MJ, Anwyl R (1996) The selective neuronal NO synthase inhibitor 7-nitro-indazole blocks both long-term potentiation and depotentiation of field EPSPs in rat hippocampal CA1 in vivo. J Neurosci 16:418-424.

Duvarci S, Nader K (2004) Characterization of fear memory reconsolidation. J Neurosci 24:9269-9275.

Edeline JM, Weinberger NM (1992) Associative retuning in the thalamic source of input to the amygdala and auditory cortex: receptive field plasticity in the medial division of the medial geniculate body. Behav Neurosci 106:81-105.

Favata MF, Horiuchi KY, Manos EJ, Daulerio AJ, Stradley DA, Feeser WS, Van Dyk DE, Pitts WJ, Earl RA, Hobbs F, Copeland RA, Magolda RL, 
Scherle PA, Trzaskos JM (1998) Identification of a novel inhibitor of mitogen-activated protein kinase kinase. J Biol Chem 273:18623-18632.

Fendt M, Fanselow MS (1999) The neuroanatomical and neurochemical basis of conditioned fear. Neurosci Biobehav Rev 23:743-760.

Frey U, Morris RG (1997) Synaptic tagging and long-term potentiation. Nature 385:533-536.

Gabriel M, Saltwick SE, Miller JD (1975) Conditioning and reversal of short-latency multiple-unit responses in the rabbit medial geniculate nucleus. Science 189:1108-1109.

Gaete J, Kameid G, Alvarez J (1998) Regenerating axons of the rat require a local source of proteins. Neurosci Lett 251:197-200.

Ganguly K, Kiss L, Poo M (2000) Enhancement of presynaptic neuronal excitability by correlated presynaptic and postsynaptic spiking. Nat Neurosci 3:1018-1026.

Gerren RA, Weinberger NM (1983) Long term potentiation in the magnocellular medial geniculate nucleus of the anesthetized cat. Brain Res 265:138-142.

Giuditta A, Kaplan BB, van Minnen J, Alvarez J, Koenig E (2002) Axonal and presynaptic protein synthesis: new insights into the biology of the neuron. Trends Neurosci 25:400-404.

Hennevin E, Maho C, Hars B (1998) Neuronal plasticity induced by fear conditioning is expressed during paradoxical sleep: evidence from simultaneous recordings in the lateral amygdala and the medial geniculate in rats. Behav Neurosci 112:839-862.

Holscher C, McGlinchey L, Anwyl R, Rowan MJ (1996) 7-Nitro indazole, a selective neuronal nitric oxide synthase inhibitor in vivo, impairs spatial learning in the rat. Learn Mem 2:267-278.

Huang YY, Martin KC, Kandel ER (2000) Both protein kinase A and mitogen-activated protein kinase are required in the amygdala for the macromolecular synthesis-dependent late phase of long-term potentiation. J Neurosci 20:6317-6325.

Josselyn SA, Shi C, Carlezon Jr WA, Neve RL, Nestler EJ, Davis M (2001) Long-term memory is facilitated by cAMP response element-binding protein overexpression in the amygdala. J Neurosci 21:2404-2412.

Kapp BS, Frysinger RC, Gallagher M, Haselton JR (1979) Amygdala central nucleus lesions: effect on heart rate conditioning in the rabbit. Physiol Behav 23:1109-1117.

Ko GY, Kelly PT (1999) Nitric oxide acts as a postsynaptic signaling molecule in calcium/calmodulin-induced synaptic potentiation in hippocampal CA1 pyramidal neurons. J Neurosci 19:6784-6794.

Kullmann DM, Nicoll RA (1992) Long-term potentiation is associated with increases in quantal content and quantal amplitude. Nature 357:240-244.

Lamprecht R, LeDoux J (2004) Structural plasticity and memory. Nat Rev Neurosci 5:45-54.

LeDoux JE (2000) Emotion circuits in the brain. Annu Rev Neurosci 23:155-184

LeDoux JE, Farb C, Ruggiero DA (1990) Topographic organization of neurons in the acoustic thalamus that project to the amygdala. J Neurosci 10:1043-1054.

Lennartz RC, Weinberger NM (1992) Frequency-specific receptive field plasticity in the medial geniculate body induced by pavlovian fear conditioning is expressed in the anesthetized brain. Behav Neurosci 106:484-497.

Liao D, Jones A, Malinow R (1992) Direct measurement of quantal changes underlying long-term potentiation in CA1 hippocampus. Neuron 9:1089-1097.

Lin XY, Glanzman DL (1994) Hebbian induction of long-term potentiation of Aplysia sensorimotor synapses: partial requirement for activation of an NMDA-related receptor. Proc R Soc Lond B Biol Sci 255:215-221.

Lisman JE, Harris KM (1993) Quantal analysis and synaptic anatomy-integrating two views of hippocampal plasticity. Trends Neurosci 16:141-147.

Lu YF, Kandel ER, Hawkins RD (1999) Nitric oxide signaling contributes to late-phase LTP and CREB phosphorylation in the hippocampus. J Neurosci 19:10250-10261.

Malenka RC, Nicoll RA (1993) NMDA-receptor-dependent synaptic plasticity: multiple forms and mechanisms. Trends Neurosci 16:521-527.

Malenka RC, Nicoll RA (1999) Long-term potentiation-a decade of progress? Science 285:1870-1874.

Maren S (1999) Long-term potentiation in the amygdala: a mechanism for emotional learning and memory. Trends Neurosci 22:561-567.
Maren S (2001) Neurobiology of Pavlovian fear conditioning. Annu Rev Neurosci 24:897-931.

Maren S, Fanselow MS (1995) Synaptic plasticity in the basolateral amygdala induced by hippocampal formation stimulation in vivo. J Neurosci 15:7548-7564.

Maren S, Yap SA, Goosens KA (2001) The amygdala is essential for the development of neuronal plasticity in the medial geniculate nucleus during auditory fear conditioning in rats. J Neurosci 21:RC135(1-6).

Maren S, Ferrario CR, Corcoran KA, Desmond TJ, Frey KA (2003) Protein synthesis in the amygdala, but not the auditory thalamus, is required for consolidation of Pavlovian fear conditioning in rats. Eur J Neurosci 18:3080-3088.

Martin KC, Michael D, Rose JC, Barad M, Casadio A, Zhu H, Kandel ER (1997a) MAP kinase translocates into the nucleus of the presynaptic cell and is required for long-term facilitation in Aplysia. Neuron 18:899-912.

Martin KC, Casadio A, Zhu H, Yaping Zhu, Rose JC, Chen M, Bailey CH, Kandel ER (1997b) Synapse-specific, long-term facilitation of Aplysia sensory to motor synapses: a function for local protein synthesis in memory storage. Cell 91:927-938.

McDonald AJ (1998) Cortical pathways to the mammalian amygdala. Prog Neurobiol 55:257-332.

McKernan MG, Shinnick-Gallagher P (1997) Fear conditioning induces a lasting potentiation of synaptic currents in vitro. Nature 390:607-611.

Milner B, Squire LR, Kandel ER (1998) Cognitive neuroscience and the study of memory. Neuron 20:445-468.

Murphy GG, Glanzman DL (1996) Enhancement of sensorimotor connections by conditioning-related stimulation in Aplysia depends upon postsynaptic $\mathrm{Ca}^{2+}$. Proc Natl Acad Sci USA 93:9931-9936.

Murphy GG, Glanzman DL (1997) Mediation of classical conditioning in Aplysia californica by long-term potentiation of sensorimotor synapses. Science 278:467-471.

Nader K, Schafe GE, Le Doux JE (2000) Fear memories require protein synthesis in the amygdala for reconsolidation after retrieval. Nature 406:722-726.

Nikonenko I, Jourdain P, Muller D (2003) Presynaptic remodeling contributes to activity-dependent synaptogenesis. J Neurosci 23:8498-8505.

Poremba A, Gabriel M (2001) Amygdalar efferents initiate auditory thalamic discriminative training-induced neuronal activity. J Neurosci 21:270-278.

Quirk GJ, Repa C, LeDoux JE (1995) Fear conditioning enhances shortlatency auditory responses of lateral amygdala neurons: parallel recordings in the freely behaving rat. Neuron 15:1029-1039.

Roberts AC, Glanzman DL (2003) Learning in Aplysia: looking at synaptic plasticity from both sides. Trends Neurosci 26:662-670.

Rodrigues SM, Schafe GE, LeDoux JE (2004) Molecular mechanisms underlying emotional learning and memory in the lateral amygdala. Neuron 44:75-91.

Rogan MT, Staubli U V, LeDoux JE (1997) Fear conditioning induces associative long-term potentiation in the amygdala. Nature 390:604-607.

Romanski LM, LeDoux JE (1993) Information cascade from primary auditory cortex to the amygdala: corticocortical and corticoamygdaloid projections of temporal cortex in the rat. Cereb Cortex 3:515-532.

Schafe GE, LeDoux JE (2000) Memory consolidation of auditory pavlovian fear conditioning requires protein synthesis and protein kinase $\mathrm{A}$ in the amygdala. J Neurosci 20:RC96(1-5).

Schafe GE, Atkins CM, Swank MW, Bauer EP, Sweatt JD, LeDoux JE (2000) Activation of ERK/MAP kinase in the amygdala is required for memory consolidation of pavlovian fear conditioning. J Neurosci 20:8177-8187.

Schafe GE, Nader K, Blair HT, LeDoux JE (2001) Memory consolidation of Pavlovian fear conditioning: a cellular and molecular perspective. Trends Neurosci 24:540-546.

Schafe GE, Bauer EP, Rosis S, Farb CR, Rodrigues SM, LeDoux JE (2005) Memory consolidation of Pavlovian fear conditioning requires nitric oxide signaling in the lateral amygdala. Eur J Neurosci, in press.

Schuman EM, Madison DV (1991) A requirement for the intercellular messenger nitric oxide in long-term potentiation. Science 254:1503-1506.

Son H, Lu YF, Zhuo M, Arancio O, Kandel ER, Hawkins RD (1998) The specific role of cGMP in hippocampal LTP. Learn Mem 5:231-245.

Steward O, Schuman EM (2001) Protein synthesis at synaptic sites on dendrites. Annu Rev Neurosci 24:299-325.

Suzuki Y, Ikari H, Hayashi T, Iguchi A (1996) Central administration of a 
nitric oxide synthase inhibitor impairs spatial memory in spontaneous hypertensive rats. Neurosci Lett 207:105-108.

Sweatt JD (2004) Mitogen-activated protein kinases in synaptic plasticity and memory. Curr Opin Neurobiol 14:311-317.

Tobias GS, Koenig E (1975) Axonal protein synthesizing activity during the early outgrowth period following neurotomy. Exp Neurol 49:221-234.

Toni N, Buchs PA, Nikonenko I, Povilaitite P, Parisi L, Muller D (2001) Remodeling of synaptic membranes after induction of long-term potentiation. J Neurosci 21:6245-6251.

Weinberger N (1982) Sensory plasticity and learning: the magnocellular medial geniculate nucleus of the auditory system. In: Conditioning: representation of involved neural function (Woody CD, ed), pp 697-710. New York: Plenum.

Yaniv D, Schafe GE, LeDoux JE, Richter-Levin G (2001) A gradient of plas- ticity in the amygdala revealed by cortical and subcortical stimulation, in vivo. Neuroscience 106:613-620.

Zakharenko SS, Zablow L, Siegelbaum SA (2001) Visualization of changes in presynaptic function during long-term synaptic plasticity. Nat Neurosci 4:711-717.

Zheng JQ, Kelly TK, Chang B, Ryazantsev S, Rajasekaran AK, Martin KC, Twiss JL (2001) A functional role for intra-axonal protein synthesis during axonal regeneration from adult sensory neurons. J Neurosci 21:9291-9303.

Zhuo M, Hu Y, Schultz C, Kandel ER, Hawkins RD (1994) Role of guanylyl cyclase and cGMP-dependent protein kinase in long-term potentiation. Nature 368:635-639.

Zou LB, Yamada K, Tanaka T, Kameyama T, Nabeshima T (1998) Nitric oxide synthase inhibitors impair reference memory formation in a radial arm maze task in rats. Neuropharmacology 37:323-330. 